Abstract

\title{
GLASSES CONTAINING COBALT OXIDE, III
}

By K. Fuwa

In the present study, first of all, several sample glasses have been made by replacing one after another the lime contents with cobalt oxide while keeping constant the amounts of alkali and silica contents in alkali-lime-silica glass. Examination have been given in these glasses with respect to how the chemical properties therein are changed as the amount of cobalt oxide increases and the amount of lime decreases.

The effects on chemical properties have been studied according to the changes in the solubility on water, $20.24 \% \mathrm{HCl}, 2 N$-sodium carbonate solution, and $2 N_{\text {-sodium hydroxide }}$ solution, by employing the powder method.

As a result of experiments it has been found that no marked changes have occurred in the solubility of glasses due to the alterations of both lime and cobalt oxide contents in glass compositions however, in the case where the amount of lime and that of cobalt oxide are equal the solubility thereof has been observed to be slightly greater than in other cases. And it has also been found that the solubility of glasses with respect to hydrochloric acid is always small and not changed, with irrespective to the amounts of lime and cobalt oxide contents in the composition of glasses.

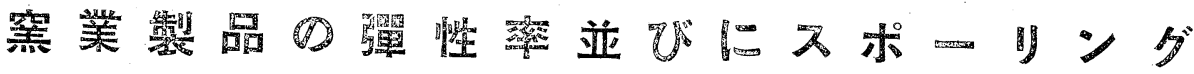 に關，する る葶 察(第 1 報)}

\section{鈴 木 信一}

彈性率は、スポーリングと密接に關係がある事は良く知られてる る、スポーリングに關して考察をなすべき前提として，先つ彈性率 の測定上の困難, 及び之が可塑性變形々不可分の相關性を有するこ とを指摘した、窯業製品に就ては，斯かる意味から，彈性率は極め て重大視すべきである。

\section{染馀}

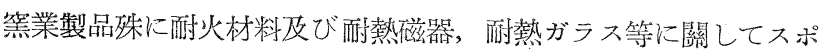
ーリングの試驗法が規格化されて居ら奴爲に, 諸家の哳究結果を簡 單に比較したり, 或は材料の優劣を判迦するのに不便を感ずる事が 赻くない, 研究者としても, 自己の呼究對象とする材料の耐蓺試驗 の實施に際し, 適確なる信念を以て賽簽し得るとは言ひ得ない。沉 やこれが第三者に取つてどれ程の客觀性を與へるか, 大いに疑問で ある、スポーリングと彈性率との間には䇦知の關係が存在し, 一般 に認容せられてるるために, 彈性率を測定してその結果から一潽普 遍性を奇與せしめようとすることも考へられる。

筆者は本報に於て，スポーリング及び撣性率に若干の考察を下し てみた.

郎ち，吾人がより普遍的性質なりと斷定して居る所の彈性率なる ものが，果して筧業䡛品に於ても何等矛盾せ奴か否かの問題であ る.

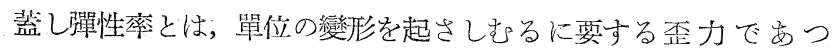

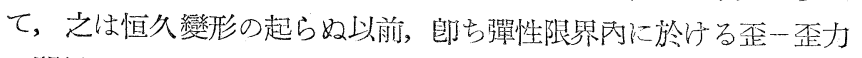
の關係から定義せられる. 換言すれば Hooke の法則の成立を前提 條件としてるるのである.

然るに，結晶內部に於ける相互作用の力を，吸引力と反撥力とに
分けて考へ，前者を焦，後者を正の符號にて表示すれば，粒子間距 離 $r$ に就ては一般式 (1) が成立する.

$$
f=\frac{m A}{r^{m+1}}-\frac{n B}{r^{n+1}} .
$$

然して安定本衡ならば $n>m$ である。

（1）式を $\Delta r$ に關して展開すれば，(2)式を得る。

$$
f=f_{0}+f^{\prime} \Delta r+\frac{1}{2.1} f^{\prime \prime}(\Delta r)^{2}+\frac{1}{3.1} f^{\prime \prime \prime}(\Delta r)^{3}+\cdots \cdots(2)
$$

Hooke の法則とは, (2) 式の第 3 項以下を省略し, 且つ $f_{0}=0$ と 置いた場合に過ぎない。刨ち

$$
f=f^{\prime}{ }_{0} \Delta r
$$

更に實驗值に就て考へれば，彈性限界とは，單に實驗的精度と實 羷誤差との函數であり，つ委り工學的實驗にては盆々彈性限界が擴 大せられることを知るので岁る，之を換言すれば工學的實驗に於て は，Hookeの法則からの偏奇が觀測される以前に，既に恒久變形が 既に現れてるることが尠くない，茲に於て彈性率测定法の困難が预 想せられる。光 を圖に示せば, 第 1 圖の零點战 近い小部分のみ が彈性限界とし て認定し得らる るのである. 從つて吾人は 可塑性變形が, 常に混同せられ
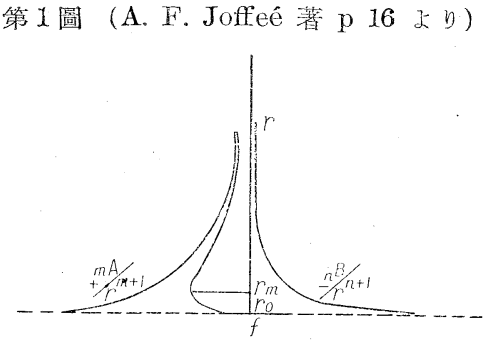
て計算されてるることを注意せねね゙ならない，再び第1圖を例に取 るならば，曲線が直線部分を超光ぬ內に，既に可塑性變形が出現し てるるのである、

結晶體の場合，恒久變形とは顯微筧的に表現すれば，單一結晶間

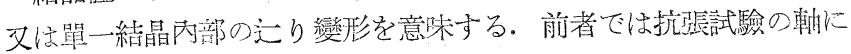

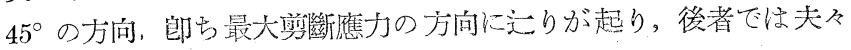
結晶體特有の結晶面冈に文りが現れるもので岁る。

恒久變形は必ずしも彈性限界を超ゆるものでなく，荷重速度に依 つて退速が生ずる。高溫度になればなるほどこの影響が小となる。

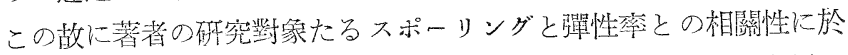

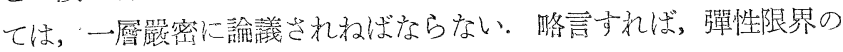
大さは溫度の上昇すると共に減少し，熔融墨に於ては殆ど零に近く なり，液態となれば需となる。彈性限界值が小であればある程，彈

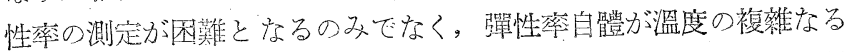
函數であるために，噘格なる定義の下では，箘業製品の彈性率は溫 度の上舁と共にこの普遍性を林䊏せしめられる。

上述した如く恒久變形の蛞發は荷重速度により左右せらるる他 に，彈性後效果又は彈性履歷現象に就て述べねばならない。これは 吾人の研究する翼在固體，殊に弿業製品に於ては餘りにも彈性體と しての本性を缺如してるるからでも市る。

一般に知らる 如く，普通の固體に應力を作用せしめれば，歪は 時間の經過に從つて霄大寸るものである。外力を作用し最初に起つ た變形に續いて，數ヶ月後には一種の筒逼兒象が觀察し得る. 外力 を除去すると大部分の歪は音波の速度を以て消失するけれども, 恒 久變形殁殘留し, 然も之も徐々に消失して行き, 見掛上は禹に角最 初の狀態に復歸する，㥛限的微小速度を以て外力を作用す兑ば可逆 變化を得るけれども, 然らざれば當然エネルギーの消費を起し, 彈 性履歷を招來する，振動は彈性後效果の結果として材料の疲勞を來 すことは, 常識上の事實でもある, 彈性後效果は不均質物體の不視 則性により，彈性限界を超えたり，又は物體內の脆弱部分の破壞に 歸因し，或は結晶粒子間の相互作用に由來寸る。い交等溫彈性率を $E i$ とし，隰熱彈性率を $E a$ とすれば，

$$
E_{i}-E_{a}=J \frac{\alpha_{1} \alpha_{2} T}{\delta C_{v}}
$$

なる關係がある，但し (4) 式中， $J$ : 熱の仕事賞量, $\alpha_{1}$ 友び $\alpha_{2}$ : 夫 々結晶主軲及び之に垂直方向の熱膨脹係數， $T$ : 縃對溫度, $C_{v}$ : 恒容 比熱， $\delta:$ 物體の密度で女る。

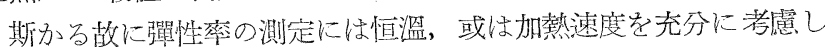
て，熱膨脹に上り起る歪が彈性率に誤差を來さ奴やうにすることが 必胴である。

著者は單に結晶聚合體或は單結唱のみの現象を引用したが，窯業 製品の場合には，成形法によつて組織に變化が起るのみでなく，一 定の條件下に成形した試料でも，既に不均質性が發生することを考 虑するならば，如何にこの種の實驗が困難であるか心゙分る，粒度，粒 形，混合比，結合齊，成形水量，成形法，燒成火度による岩石學的 微構造の差異等の如く，一種類の材料に於てすら，その結果は甚だ 複雜であつて，测定法の良否は，この意味にて洪定的な要素なりと 言はねばならない。

結晶體に於て可塑性變形と云ふのは，結晶の过りが，或一定の結 晶學的方向にの2起り，四轉運動学件はない場合であり、メ線的に 檢べる時は，以前結晶性を示して居らずして fiberons structure 艺 與へる。

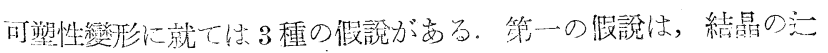

りの周波數が單位時間の汇りの數に等しいこと, 且つ之は外力 $P$ と 彈性限界值 $P_{0}$ との差の函數

$$
Z=\frac{\Delta N}{\Delta t}=F\left(P-P_{0}\right)
$$

そ考へ，可塑性變形の速度 $S$ は

$$
V_{p}=\frac{\Delta S}{\Delta t}=Z S
$$

可塑性變形によつて彈性讋が埥加する事を，材料學者は低溫加工 と名づけてるる。

第二の假說は, 或面に於ける方りは原子構造の規則性を破壞し, 原子程度尺度を以て言ひ表せば，表面が粗となる。この不規則性は

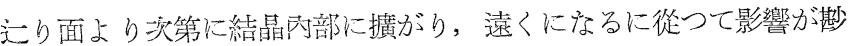
いと考へる。單位の長さに對する方りの數に比例して彈性限界值が 增加する事, 並びに等間隔に它り面が發生してるる事は共にこの假 說で說明し得る。

第三の假說は，單一小片に聍へられた彈性エネルギーの放散が， 郎ち方りであるとするるのである、妾り面は破壞された所の格子で あつて，最初の狀態より高いエネルギー狀態に岁るとする。音波が 全結晶を傳播するよりも大なる速度で汇りが起れば，エネルギーは 隣接表面中の結晶の小部分により，供給せられねばならないそれれ 故にエネルギーが1個又は數個げけの小片から吸收されると考へ得 る. 從つて, 厚さ $D$ なる小片の $U$ エネルギーは, 歪力 $p$ の表面 $S$ の時は

$$
\begin{aligned}
& \text { 且つ完りに要するエネルギーは } \\
& \qquad U_{2}=2 \propto S
\end{aligned}
$$

然して新しい它りを生ずる最小の歪力が，郎ち彈性限界であるか b,

$$
p_{0} \doteq 2 \sqrt{\frac{Q}{E^{2}}} \cdot \sqrt{\frac{1}{D}}
$$

（7）式は小片の均質性友び低溫加工に因る彈性限界值の上昇を說 明してるるものである。

元來殆ど凡ての岩石には, 常溫に於てb Hooke の法則が適用出 來ない(日下部博士著 地震學沉論)。然して岩石の彈性的降伏值 $\eta$ は,時間の函數にして次式で表示されるとしてるる(日下部氏：Jour. Corl. Sci. Tokyo, 1908, 19 Art. 6).

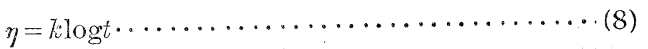

彈性後效果の本性に就ては, 多數の研究者により賔驗せられ, Wiechert. 氏 (Ann. der Plys.1893,50,335) 质びA. A. Michelson 氏 (Amer. Acad. Sci. 1916，313) 等は，後效果は函數或はその和で表示 せられるとした。

H. V. Wartenberg E (Verh. d. Deut. Phys. Gesell 1918, 113) は，タングスデン皮び亞鉈金濁に就て實驗した結果，結晶が非常に 大きい時质び液體空氣の低溫度では，後效果並びに履歷現象は觀察

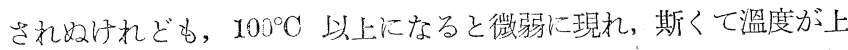
昇するに從つて可塑性が壖加して行き，一曆高溫度とな光ば再び減 ずると報じた。

Mcconnel 度び Kidd 网氏は (Proc. Roy. Soc. London, 1883, 44,331) 承に就て實驗し，可塑性變形に關し次の如き考察を立證し

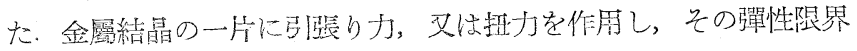

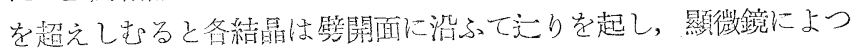

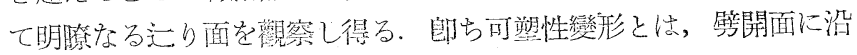
ふ立りに原因するものとした，降伏點を超えて變形を續けしむれば

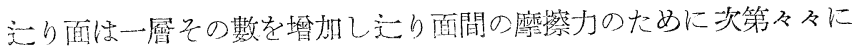


變位を起すに到り，斯くて引張り力又は扭れ力の作用は，逐に顊性 後效果攻ず履歷現象を惹起するものとした

大久保氏は (The Sci. Rep. of the Tohoku Imp, Univ. 1922, 11, 173）針金の引張試驗を行ひ次の考察を下した、引張り力を作用する と剪斷力の合力は, 力の方向に $45^{\circ}$ の傾斜を以て作用し, 过り面は この剪斷力面に沿ふて起る.今金屬が無限小の厚さを有する結晶層 の聚合體より成るものとすれば，これ等の厥間の境界面の艺らに摩 擦力が作用し，この摩擦力は迄り速度に比例する。郎ら固定點より $l$ なる距離にある點の變位。 $D$ は次式で表されるとした。

$$
D=a e^{-\frac{k}{2}\left(l_{0}-l\right)} \cos \left\{p t-\frac{k}{2}\left(l_{0}-l\right)\right\}
$$

（9）式から彈性後效果友び履歷現象を考へるに，D品ら l 點の變 位の振幅は exp.- $\frac{k}{2}\left(l_{0}-l\right)$ に從つて減少する. exp. $-\frac{k}{2}\left(l_{0}-7\right)$ は位 相差であつて， $l$ 點に引張り作用が到達するには，(10) 式で示され るだけの時間を要する。

$$
\left(l_{0}-l\right) \sqrt{\frac{\rho}{2 p \mu}}
$$

但し, $\mu$ : 摩擦係數, $\rho$ : 密度

今 $p t$ を橫軸にとり, $l$ 點の變位 $D$ を縱軸にとれば，第 2 圖を得 る. 圖中 $\mathrm{OA}$ は $\exp -\frac{k}{2}\left(l_{0}-l\right)$ に等しく, OB $\left(l_{0}-l\right) \sqrt{\frac{\rho}{2 \rho \mu}}$ に 等しい. 又變位. $D$ を縱蟿に, 荷重 $a \cos \mathrm{pt}$ を橫軸にとつて伸長一 荷重曲線を描けば第 3 圖を得る。
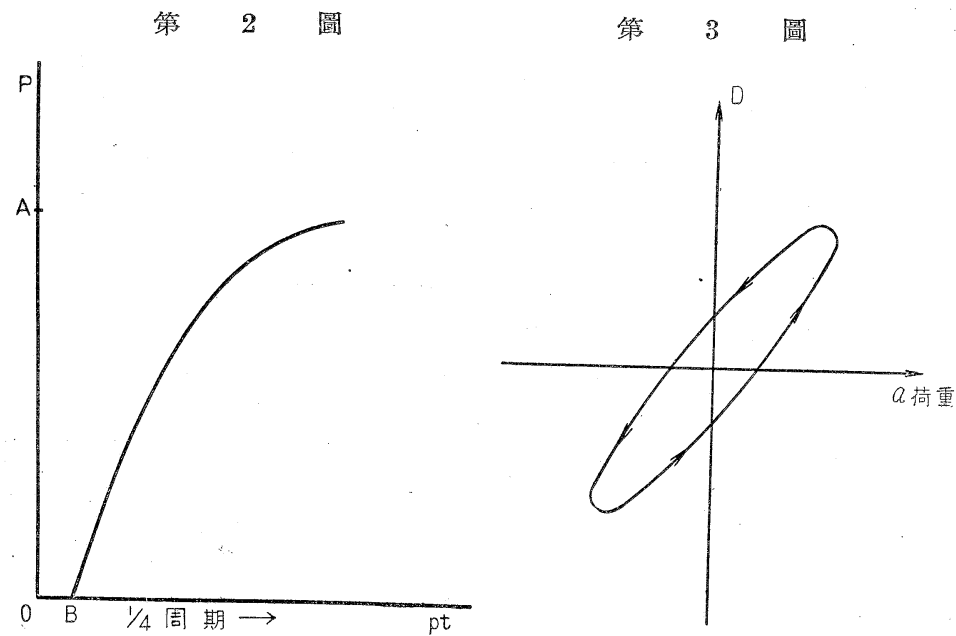

次に睯性線の彎曲性に就て考へよう，彈性限界內では應力一歪曲 線は直線となるべき筈である事は既述した。然して實驗上の精度が 高くならほどこの事實は逆になり，直線とはならずに彎曲してくる。 この狀沉を表示すると第 4 圖の如くである. 從つて蒘性率を決定す

第 4 圖

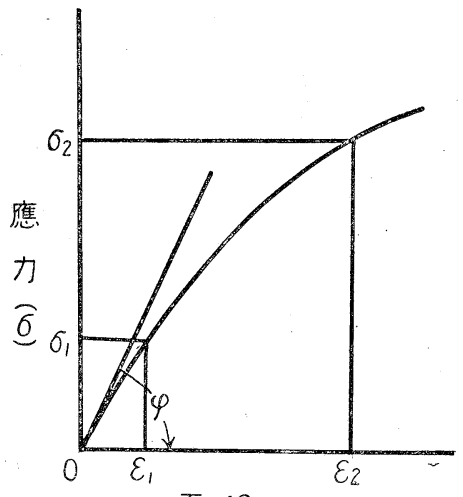

歪 $(\varepsilon)$
る事が出來ないことにな る. 便宜上では原點に於て $\tan \varphi$ を求めるか（郎ち曲 線に切線を引く)，或は彈 性率 $E$ の平均值を $E=$ $\frac{\sigma_{1}-\sigma_{2}}{\varepsilon_{1}-\varepsilon_{2}}$ から算するか何れふ の方法をとる。一般的に云 ふならば歪 $\varepsilon$ は，應力 $\sigma$ との間に

$$
\varepsilon=a \sigma+b \sigma^{2}+c \sigma^{3}
$$

又は

$$
\varepsilon=a \sigma^{n}
$$

の如き式を考へねばなら
ぬ.この場合 $n$ は實驗上種々の値が報告せられ，例へば銅 (唇力) $=$

\begin{tabular}{|c|c|c|}
\hline & 第 & \\
\hline 材 料 名 & $E_{\mathrm{Ig} / \mathrm{mm}^{2}}$ & 實 驗 者 \\
\hline アルミニウム & 7200 & Slotte \\
\hline $\begin{array}{l}\text { アルミニ } \\
(\text { (口出 }\end{array}$ & 7400 & Baumann \\
\hline 鉛（硬 引） & 1803 & Werthein \\
\hline 鋼 (硬 引) & 21600 & Grüneisen \\
\hline$=ッ ケ ル$ & 22790 & Cantone \\
\hline ニッケル鍴 & 19900 & Mercadier \\
\hline 銀 & 7010 & Katzenels \\
\hline 鉛 & $873 t$ & Werthein \\
\hline 切子矿子 & 6890 & Chevandier \\
\hline ポヘミヤ确子 & 7535 & Pscheidl \\
\hline フリント确子 & 5500 & Canton \\
\hline 水 晶 & 6900 & Auerbach \\
\hline 石英ガラス & 6239 & Schulze \\
\hline 水 晶 籍 & 6238 & Schulze \\
\hline 么 & $0.02 \sim 0.8$ & Schulze \\
\hline 竹 & 3000 & Werthein \\
\hline
\end{tabular}
1.093，鑄鐵 (張力) $=1.066$ で岁る (Auerbach-Hort; Handbuch Phys. Tech. Mech. 1931, 4)

今參考のために數種の物質に就て常溫度の彈性率を揭示する。

彈性率の測定法は，試料の材質如何によつて適否のある のは勿論であるが，更に䔂業製品でも，ガラス，コシクリ 一ト, 陶磁器, 耐火材料 (耐火材料の中でも嚴密に云ふな らば, 鹽基性, 中性, 酸性及びシャモッ卜質によつて異る であらうに應じ，夫々周到に考案されねばならない。

一體彈性率の測定は，試料に外力を作用してるる時に， 試料中の各部分が何れる彈性變形の久起してるること, つをり可塑性變形が絕對に發生してるないこと，を假定し てるるのである. 然して實驗誤差を最小限度に止めよろと するならば，內力の分布狀態が出來るだけ簡單になるや引 に工夫せねばならない。

彈性率の測定法としては

（1）針金又は試驗棒の弓張試驗法,

(2) 梁の彎曲による試驗法,

(3) 振動法,

(4) 振り實驗法より橫彈性係數を知り $E$ を算する方法 $\left(E=\frac{2(m+1)}{m} G, m:\right.$ ポアソン比),

等が一般的で岗るが，箽業製品に對しては (1) 及び (3) は不可能に 近い方法と云はねばならない,(2) の方法では撓夕量 $\varepsilon$, 荷重 $W$, 支 點間距離 $l$ ，斷面の幅 $b$, 高さ $h$ とすれば

$$
E=\frac{W l^{3}}{4 \varepsilon b h^{3}}
$$

から求められる。

(3) の方法は，音波が固體中を傳播するときに，音波速度 $V$ ，固體 の密度 $\rho$ とすれば

$$
E=V^{2} \rho \quad\left(\text { dyne } / \mathrm{cm}^{2}\right) \cdots \cdots \text { 絕體單位 }
$$

の關係が成立することを利用するものであつて，(之を $\mathrm{kg} / \mathrm{mm}^{2}$ 單 位に換算するには $980 \times 10^{5}$ で除さねばならない）これには試驗棒 を一定の場所で摩擦して音を發生せしめ, その振動數 $N$ は原音の時 は $V=2 i N$ であるから結局 $E$ は

$$
E=\frac{(2 N l)^{2} \rho}{9500} \mathrm{~kg} / \mathrm{mm}^{2}
$$


但し : は棒の長さを米で表したものである.

この方法は陶磁器又ガラスの場合には實驗し得るも, 有孔性を有 する材料では複雜なる結果となるですらう事は推測し得るに難くな い.（4）の方法では試驗棒の直敒 $D$, 長さ $l$, 椢轉角 $\theta$ (但し弧度), 㨝りのモーメント $T$ とすれば

$$
G=\frac{32 T l}{\pi D^{4} \theta} \ldots \ldots \ldots \ldots \ldots \ldots \ldots \ldots \ldots \ldots \ldots \ldots \ldots \ldots \ldots \ldots
$$

より橫彈性率を算出し得る。

スポーリングに關聯して彈性率は，急冷試驗溫度に相當する值を 測定せね齐ばなら㰠め, 實驗上の誤差が倍加されるのである.

彈性率は溫度の上昇するに從つて減少するものであつて，溫度の 餘り高くない時は $E_{t}=E_{0}(1-c t)$ の如き直線式が成立するけれど

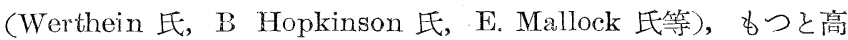
溫度迄に就て實驗すれば $E=E_{0}\left(1-\alpha t-\beta t^{2}\right)$ の如き形を得る $(\mathrm{H}$. M. Dadurian, Phil. Mag. 1921 42, 442). K. Koch 氏 (Ann. der Phys. 1922 68,441) は各種の金屬に就て融點迄の $E$ を求め, 上記 の事實と同じやうな曲線的關集を與へてるる，金屬以外の材料に於 ては, 溫度による $E$ の變化は非常に大きい。茲で當然高溫度に於 ける可塑性變形の問題が對象となるのである。

黑田正夫氏（理研葷報 Vol. 10，No. 12 及び Vo'. 11, No. 11) は軟鑛の索引詃驗を，常溫度より $300^{\circ} \mathrm{C}$ 迄の溫度範圍に就て行ひ， 所謂降伏點に關して新しい解釋を加へた。同氏によれば鋼の境界組 織が重大なる役割を演ずるものであつて，高溫度に於てはこの境界 組織は粘性を增加してその影響を減少して來る。

嚴密に觀察するならば，固體は，充分に長期間繼續的に力が加一 られてるると，漸次に變形して行く。郎ち，クリープ限界試驗が問 題にせられる所以である。高溫度のクリープ限象に就て R. W. Bailey 氏 (Egg. 1925, 119,518) 及び P. G. Mevetty 氏(Tron Age. 1931，127，868）の見解を引用寸れば，次の通りである。內部の云り により生じた歪效果が熱化により破壊する作用と，次の芒りに依り 生ずる歪效果とが平衡に達した場合の狀態，即ち永續的に增加する 粘性的變形を示すものである

筧業製品の恒久變形に就ては・F. H. Norton 氏 (Jour.Amer。 Cer. Soc. 1936 19，129）の見解を引用する必要があらう。墨業製品
の長期間に唒る徐々に進行する變形には 3 種類ある.郎ち

（1）定時間後には變形の大さが歪力に正比例する場合，乞の例と しては加熱されてるるガラスの可塑性變形,

(2) 可塑性變形に於て一定時間後變形の割合が減少 乙. 大體變形 が歪力の 4 乘に比例する.之は金屬の兩結晶溫度以上に於ける變形 の場合の如く，結晶及びガラス質を含むが如き窯業製品ではこの種 の變形を示すもので岁つて，その理由は軟質基地中に剛性粒子を散 在してるるからである，

(3) 彈性變形では破壊點迄變形速度が零である.この種の變形に 對しては實驗が困難であるために餘り䃏究されてるない。

完全に彈性的性質を示寸團體は存在しないから，實驗上の注意は 低變形率に於て行はれる事か泌要である。

窐業製品の可塑性變形に就ては近滕清治氏及び著者の實驗報告が 一部分發表せられてるる (工業化學雜誌, 昭和 10 38, 309; 同, 昭和 $12,40,619$ )

J. H. Partridge 及び G. F. Adams 兩氏 (Jour. Soc. Glass. Tech, 1931，15，190）の報告は，䈎業製品の可塑性變形に就て研究した最 初の實驗である。

倥業製品中ガラ大を除いては，材料が燒成中に起る素地變形，荷 重下に於ける耐火材料の變形等は從來良く研究されてるる. 例一 ば，ゼーゲル錐で測定した熔融點は，11b/口゙の歪力の下に，100\%/hr の割合で恒久變形を起すべき溫度を意味してるる。それ故に恒久變 形曲線は, 實用上耐火材料の物理的性質を說明するに便利であり, 融點を精確に定義できる。

F. H. Norton 氏は恒久變形率に就て次式を得た.

$$
\begin{aligned}
& V=k_{1} F^{a}(\text { 定溫度 }) \cdots \cdots \cdots \cdots \cdots \cdots \cdots \cdots \cdots \cdots \cdots(15) \\
& t=k_{2} \log F+b \text { (定恒久變形率) } \cdots \cdots \cdots \cdots \cdots \cdots \cdots(16)
\end{aligned}
$$

茲に $V$ : 恒久變形率, $F$ : 歪力, $t$ : 溫度, $a, b, k_{1}, k_{2}$ : 定數. 注意すべきは, 試料の熱處理が重大なる影響を有すると云らこと である。

本䂠究に對し, 終始御稂切なる御指導を賜りたる恩師東京工業大 學敉授工學博士近藤清治先生, 並びに本研究所員工學博士谷口忠先 生に深蒜なる謝意を表する者である。

\section{ゼ一ゲル 錐 の 製 造 硎 觉(第 1 報) 長 石類に關するる試驗}

\section{仲 并 俊・雄・深 見 芳 雄}

長石は主要なる器業原料の一にして陶磁器の素地, 釉藥乞の他篣 業方面に多量に使用せらる。また今包述べんとするゼーゲル錐の製 造に當つても亦重要なる原料なり，長石の主要なる目的は高溫燒成 の際に, 之が熔融して硝子質となりて表面を掩ひ, 或は融劑として作 用して憢成物をシンターせしめ，質堅牢とならしむるに役立つ等な り. 長石類には加里長不, 曹達長石, 石灰長石等列擧すればその種 類㥛めて多數に上るも，これ等の內，天然に最も多量に産し從つて 墨業方面にも主として使用せらるるものは，加里長石（正長不）な り、然し之等は何れも純粹なるものは極めて尠く，常に多少なりと も不純物学含有するが故にその成分は一定せず，茛地の異るに從ひ
李た同一產地のものに於ても, 採掘場所の異るによりてその成分に 著しき相違を來たす場合あり，從つて豫め充分に品質の調査を行は ざる時は，不慮の惡結果を招く恐れあり．

長石に關する研究は鑛物學，地質學及び算業界には極めて重要な る問題なるが故に, 從來幾多の研究者によつて研究されたる所なる が，然し本研究には仲々難解なる多くの問題が横たはり，今日に於

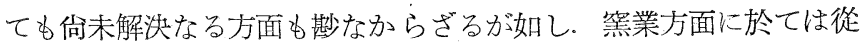
來長石の試驗法としては化學分析耐火度試驗及び颢微鏡的試驗等が 授用されたるところなるが，これらの方法とても概して充分には行 はれず，一步進めて基本的な研究には鉒り觸れて居らざる狀態な 